\title{
The representation of disability in the media in the UK and France: implications for free speech and diversity in light of Article 8 of the Convention on the Rights of Persons with Disabilities
}

\author{
Andreas Dimopoulos* \\ Lecturer in Law, Brunel University, UK
}

This article focuses on the normative content of Article 8 of the Convention on the Rights of Persons with Disabilities (CRPD), and examines its implications for the regulation of broadcasting with regards to diversity and free speech. The analysis claims that Article 8 CRPD requires a stricter approach to issues of free speech, in favour of promoting social inclusion for persons with disabilities. The article engages in a comparative examination of EU, French, and UK law on broadcasting to argue that current law and practice (focusing on disabilityrelated complaints) is inadequate to fulfil the obligations imposed by Article 8 CRPD.

Keywords: disability, media regulation, diversity, free speech

\section{INTRODUCTION}

The Convention on the Rights of Persons with Disabilities (CRPD) contains several provisions concerning the media. For instance, Article 9 CRPD, which enshrines a right to accessibility, also includes Information and Communications Technologies (ICT) in its scope. Ensuring the accessibility of ICT is crucial so that persons with disability may enjoy other human rights, such as the right to freedom of expression, under Article 21 CRPD. ${ }^{1}$ For this reason, academic writing on disability and the media has primarily focused on the issue of accessible communications. ${ }^{2}$ However, there is one other important area, besides accessibility, where disability intersects with ICT: Article 8 CRPD, which concerns awareness-raising, also refers to the representation of disability in the media. Article 8 CRPD imposes three obligations on States Parties: the first is to raise awareness throughout society, including at the family level, regarding persons with disabilities, and to foster respect for the rights and dignity of persons with disabilities. The second is to combat stereotypes, prejudices, and harmful practices relating to

* The author wishes to thank the anonymous reviewers for their insightful comments. The usual disclaimer applies.

1. UN CRPD Committee, General Comment No 2 (2014) CRPD/C/GC/2, [21].

2. See, for example, N Foggetti, 'Special Briefing-e-Accessibility Standards Definition in the UN Convention on the Rights of Persons with Disabilities: Current Issues and Future Perspectives' (2012) Computer and Telecommunications Law Review 56. 
persons with disabilities including those based on sex and age, in all areas of life. The third and final obligation is to promote awareness of the capabilities and contributions of persons with disabilities.

The normative content of Article 8 CRPD has not yet been further clarified in a General Comment by the CRPD Committee. For this reason, a thorough analysis of the drafting history of Article 8 CRPD is undertaken in the first section of this article. For the purposes of this introduction, it is important to highlight that Article 8 CRPD can be regarded as an amplification of existing human rights provisions. ${ }^{3}$ For example, Article 7 of the International Convention on the Elimination of All Forms of Racial Discrimination (CERD) imposes a similar obligation on member States to adopt immediate and effective measures, particularly in the fields of teaching, education, culture and information, with a view to combating prejudices which lead to racial discrimination and to promoting understanding, tolerance and friendship among nations and racial or ethnic groups, as well as to propagating the purposes and principles of several international human rights documents. Article 8 CRPD expands this safeguard and amplifies its impact, also by listing several indicative measures to ensure compliance with awareness-raising obligations. One of these measures is to encourage all organs of the media to portray persons with disabilities in a manner consistent with the purpose of the CRPD. The question therefore arises as to what extent fulfilling this obligation may justify interferences with free speech in the media.

In order to tackle this question, the article will take the road less travelled, and examine the normative content of Article 8 CRPD. This analysis develops a broad framework for conceptualising the obligations imposed by that provision. Article 8 CRPD aims to tear down attitudinal barriers against disability through a process of transformative equality, and to ensure the equal standing of persons with disability in social interactions. For this reason, the analysis will claim that the provision goes beyond the relatively weak protection of disability under the EU Audiovisual Media Services Directive (AMSD). ${ }^{4}$ Equally inefficient are current national law and practice, as the comparative examination of the relevant legal framework in France and UK will show. The article will focus on how telecommunication authorities in the UK and France have regulated the representation of disability in the media, with regards to several disability-related complaints about television broadcasts. Against the backdrop of this comparative analysis, the article claims that Article 8 CRPD may have considerable impact on the right to free speech in the media, by providing a substantively rich benchmark, against which complaints about media broadcasts relating to disability may be decided in a satisfactory way. The analysis will argue that Article 8 CRPD goes beyond current efforts towards diversity, which broadcasting regulators strive to promote and draw attention to the shortcomings in the reasoning that broadcasting authorities currently employ when deciding disability-related complaints. This is because, under Article 8 CRPD, one of the indicative measures to raising awareness about disability is to encourage all organs of the media to portray persons with disability in a manner consistent with the purpose of the CRPD. The article argues that this obligation may also be imposed on broadcasting regulators, and explores ways in which they can offer this encouragement to the media.

3. R Kayess and P French, 'Out of Darkness into Light? Introducing the Convention on the Rights of Persons with Disabilities' (2008) Human Rights Law Review 32.

4. Council Directive 2010/13/EU of 10 March 2010 on the coordination of certain provisions laid down by law, regulation or administrative action in Member States concerning the provision of audiovisual media services [2010] OJ L95/1. 
The first part of the analysis explores the normative content of Article 8 CRPD and argues that its interpretation must take into account concepts such as the social model of disability, disablism, and transformational equality. In essence, Article 8 CRPD provides a sound criterion for delineating the outer limits of acceptable free speech, broadcast by media: the media must portray persons with disability in a way that promotes and protects the full and equal enjoyment of their human rights, as well as respect for their inherent dignity, in accordance with Article 1 CRPD. The second part of this article closely examines the reasoning of broadcasting regulatory bodies with regards to several disability-related complaints about media broadcasts in the UK and France. The analysis criticises telecommunication authorities for not taking into account the relevant provisions of Article 8 CRPD when dealing with disability-related complaints about broadcasts, and proceeds to illustrate how these disability-related complaints could have been more satisfactorily addressed on the basis of Article 8 CRPD. In closing, the analysis suggests several ways in which telecommunication authorities must reshape media regulation with regards to how disability is represented, in light of the CRPD.

\section{AWARENESS-RAISING AND COMBATTING STEREOTYPES}

What does the obligation to encourage all organs of the media to portray persons with disabilities in a manner consistent with the purpose of the CRPD entail? The drafting history of Article 8 CRPD shows a strong consensus over the article's formulation, but does not reveal much about its substantive content. The General Assembly resolution 56/168 of 19 December 2001 established an Ad Hoc Committee to draft the CRPD. ${ }^{5}$ The seminal version of Article 8 features in the early draft of the Convention which had been prepared by Mexico, and was included in the documents of the first session of the Ad Hoc Committee in 2002. ${ }^{6}$ In the Mexico draft, Article 5 reads as follows:

States Parties shall promote the changing of stereotypes, socio-cultural patterns, customary practices, or of any other nature which constitute an obstacle for persons with disabilities or their families in the exercise of their rights. To this end, States Parties shall: ...

b) Encourage the mass media to project a positive and non-stereotype image of persons with disabilities and their families.

In the second session of the Ad Hoc Committee in 2003, the decision was taken to establish a Working Group with the aim of preparing and presenting a draft text of the CRPD, which would be the basis for negotiation by Member States. ${ }^{7}$ In order to facilitate the deliberations of the Working Group, the Chair of the Ad Hoc Committee prepared a document containing the Draft Elements of the Convention. ${ }^{8}$

5. UNGA Res 56/168 (26 February 2002) UN Doc A/RES/56/168.

6. Ad Hoc Committee on a Comprehensive and Integral International Convention on Protection and Promotion of the Rights and Dignity of Persons with Disabilities, First Session, Working Paper by Mexico (2002) A/AC.265/WP.1.

7. Ad Hoc Committee on a Comprehensive and Integral International Convention on Protection and Promotion of the Rights and Dignity of Persons with Disabilities, Second Session, Report (2003) UN Doc A/58/118.

8. Ad Hoc Committee on a Comprehensive and Integral International Convention on Protection and Promotion of the Rights and Dignity of Persons with Disabilities, Second Session, Chair's Draft Elements of a Comprehensive and Integral International Convention on Protection and Promotion of the Rights and Dignity of Persons with Disabilities (2003). 
In the Chair's draft elements, Article 8, entitled 'Changing attitudes to disability', reads as follows:

States Parties undertake to adopt immediate and effective measures, particularly in the fields of teaching, education, culture and information, civil society and the media, with a view to educating the community and combating prejudice, myths and stereotypes about the nature of disability and persons with disabilities.

The Working Group met in January 2004 and delivered the draft articles of the convention in Annex I of its Report, which was presented to the Ad Hoc Committee. ${ }^{9}$ Article 5, entitled 'Promotion of positive attitudes to persons with disabilities', reads as follows:

1. States Parties undertake to adopt immediate and effective measures to:

a. Raise awareness throughout society regarding disability and persons with disabilities;

b. Combat stereotypes and prejudices about persons with disabilities;

c. Promote an image of persons with disabilities as capable and contributing members of society sharing the same rights and freedoms as all others and in a manner consistent with the overall purpose of this Convention.

2. These measures shall include, among others: ...

a. encouraging all organs of the media to project an image of persons with disabilities consistent with the purpose of this Convention;

The draft Article 5 was discussed during the third ${ }^{10}$ and fourth ${ }^{11}$ session of the Ad Hoc Committee, with delegates being generally supportive of its formulation. The fifth and sixth sessions of the Ad Hoc Committee focused on the elaboration of other articles of the CRPD. At the end of the sixth session, the Chairman of the Ad Hoc Committee summarised the drafting process, by producing a Working Text of the Convention, which formed the basis for discussion during the seventh session of the Ad Hoc Committee. ${ }^{12}$ The Working Text positions the then draft Article 5 in Article 8, entitled 'Raising awareness regarding disability', which reads:

1. States Parties undertake to adopt immediate and effective measures:

(a) To raise awareness throughout society regarding disability and persons with disabilities, and to foster respect for their rights;

(b) To combat stereotypes and prejudices about persons with disabilities in all areas of life;

(c) To promote awareness of the capabilities and contributions of persons with disabilities.

9. Ad Hoc Committee on a Comprehensive and Integral International Convention on Protection and Promotion of the Rights and Dignity of Persons with Disabilities, Report of the Working Group to the Ad Hoc Committee (2004) UN Doc A/AC.265/2004/WG/1.

10. Ad Hoc Committee on a Comprehensive and Integral International Convention on Protection and Promotion of the Rights and Dignity of Persons with Disabilities, Third Session, Daily Summary of Discussions (2004).

11. Ad Hoc Committee on a Comprehensive and Integral International Convention on Protection and Promotion of the Rights and Dignity of Persons with Disabilities, Fourth Session, Daily Summary of Discussions (2004).

12. Ad Hoc Committee on a Comprehensive and Integral International Convention on Protection and Promotion of the Rights and Dignity of Persons with Disabilities, Seventh Session, Letter dated 7 October 2005 from the Chairman to all members of the Ad Hoc Committee (2006) UN Doc A/AC.265/2006/1. 
2. Measures to this end include: ...

(c) Encouraging all organs of the media to portray persons with disabilities in a manner consistent with the purpose of the present Convention;

During the seventh session of the Ad Hoc Committee, several minor amendments to the draft Article 8 were made (such as the revised chapeau of Article 8 from 'Raising awareness regarding disability' to 'Awareness-raising'). ${ }^{13}$ Subsequently, the Drafting Group, tasked with ensuring uniformity of terminology in the draft convention made further minor changes to Article $8 .{ }^{14}$ The eighth session of the Ad Hoc Committee adopted the finalised version of the CRPD. ${ }^{15}$

Close examination of the available documents on the drafting history of Article 8 CRPD does not provide many clues as to its substantive content. For instance, during the afternoon session of 1 September 2004, Australia 'outlined the 3 messages emerging from this article: 1. raising awareness in all aspects of society about disability and PWD, their rights, potential and contributions to society; 2 . to promote the capabilities and contributions of PWD and reinforce their positions as equal members of society; 3 . to combat negative stereotypes or negative practices and prejudices'. ${ }^{16}$ Similarly, in the afternoon session of 31 August 2004, Australia argued that 'Article 5(2)(c) addresses the media and there is an argument to be made that this should be retained as when the media portrays an image of PWD it should be positive and accurate'. ${ }^{17}$ In a similar vein, during the same session, Venezuela also 'addressed 5(2)(c) on the role of the media. The media, and television in particular, plays an important role in promoting positive attitudes to PWD, and so it is important that this concept be addressed somewhere. The media should be encouraged to help and where the media is in the private sector some incentives may need to be found to accomplish this'. ${ }^{18}$

Given the limited substantive information on Article 8 CRPD during the drafting process, this article will attempt to explain its purpose by situating it in the wider context of disability rights theory. If we accept that Article 8 CRPD is about raising awareness of disability, promoting positive attitudes, and combatting stereotypes, then key to interpreting this article, and applying it in real life situations, is the social model of disability. Article 1 CRPD defines persons with disabilities as 'those who have long-term physical, mental, intellectual or sensory impairments which in interaction with various barriers may hinder their full and effective participation in society on an equal basis with others'. These barriers need not be architectural; they may be attitudinal as well. Prejudices against disability and stereotypes of persons with disability have played a central part in the marginalisation and exclusion of

13. Ad Hoc Committee on a Comprehensive and Integral International Convention on Protection and Promotion of the Rights and Dignity of Persons with Disabilities, Seventh Session, Report of the Ad Hoc Committee (2006) UN Doc A/AC.265/2006/2.

14. Ad Hoc Committee on a Comprehensive and Integral International Convention on Protection and Promotion of the Rights and Dignity of Persons with Disabilities, Seventh Session, Drafting Group, Fourth Revised Text (2006).

15. Ad Hoc Committee on a Comprehensive and Integral International Convention on Protection and Promotion of the Rights and Dignity of Persons with Disabilities, Eighth Session, Final Report of the Ad Hoc Committee (2006) UN Doc A/61/611.

16. Ad Hoc Committee on a Comprehensive and Integral International Convention on Protection and Promotion of the Rights and Dignity of Persons with Disabilities, Fourth Session, Daily Summary of Discussions (2004).

17. Ibid.

18. Ibid. 
persons with disability. ${ }^{19}$ In the same way that Article 9 CRPD, which entrenches the right to accessibility, aims to remove architectural barriers and promote universal design, Article 8 CRPD aims to remove attitudinal barriers against persons with disability, and promote positive attitudes towards disability. Article 9 CRPD is about access to the built environment (in terms of infrastructure), whereas Article 8 CRPD concerns access to the social environment (in terms of social interactions). The significance of Article 8 CRPD cannot therefore be underestimated, and its underlying importance is evident in its strong support from delegates during the drafting process of the CRPD.

In order to better understand the attitudinal barriers that persons with disability face, it is useful to introduce to this analysis an additional concept used in disability rights theory. Disablism can be defined as 'a form of social oppression involving the social imposition of restriction of activity on people with impairments and the socially engendered undermining of their psycho-emotional well-being. ${ }^{20}$ Disablism is the belief that persons with disability are inferior to able-bodied persons, because they lack a certain ability. In this sense, language that diminishes persons with disability as inferior is disablist, and perpetuates stigma and social exclusion for persons with disabilities. As a general rule therefore, disablist language and disablist representations of persons with disabilities in the media, such as television, are not permissible under Article 8 CRPD, read together with Article 1 CRPD. The concept of disablism is therefore important in order to determine generally accepted standards and offensive language in broadcasts about disability.

A further important point about Article 8 CRPD is that it is not limited to combatting stereotypes against disability, but also imposes obligations on States Parties to raise awareness about persons with disability and promote awareness of their capabilities and contributions. These obligations should be understood in the light of transformative equality: States Parties are required to take positive measures to shape actively public opinion towards persons with disability, so that they are regarded as full and equal members of society by other citizens. In this way, Article 8 CRPD goes beyond the incomplete protection of disability rights under the AMSD, or diversity policies in national law and policy. Whereas diversity policies aim to increase the visibility of groups with different characteristics in the media, ${ }^{21}$ Article 8 CRPD requires increased visibility in ways that raise awareness of the capabilities and contributions of persons with disability, with a view of actively combatting prejudice against disability.

The social model of disability, disablism, and transformational equality from a set of principles underpinning Article 8 CRPD, which provide a good starting point as to how to interpret this provision. These principles are crucial for interpreting the obligation imposed on States Parties to encourage all organs of the media to portray persons with disability in a manner consistent with the purpose of the CRPD. Given the paramount importance of lifting attitudinal barriers and combatting disablism for the protection of the rights of persons with disability, this analysis claims that Article 8 CRPD provides a sound criterion for delineating the outer limits of acceptable free speech,

19. A Shapiro, Everybody Belongs: Changing Negative Attitudes Toward Classmates with Disabilities (Routledge, London 2000) 83.

20. D Goodley and K Runswick-Cole, 'The Violence of Disablism' (2011) Sociology of Health and Illness 604.

21. For an example in French law see art 3-1 of law No. 86-1067 of 30 September 1986 which states that the French regulatory body of broadcasting is charged with overseeing that broadcasts reflect the diversity of French society. 
published or broadcast by media. The media must not only avoid disablist language, but must also portray persons with disability in a way that promotes and protects the full and equal enjoyment of their human rights, and also promotes respect for their inherent dignity, in accordance with Article 1 CRPD, which states the purpose of the CRPD. This approach is also in line with the Rabat Programme of Action on Hate Crime (which however only addresses religious and ethnic hatred). ${ }^{22}$

Even if it is up to States Parties to decide what measures to take, these measures however, must be immediate, effective and appropriate, according to paragraph 1 of Article 8 CRPD. For this reason, the obligation to encourage all organs of the media to portray persons with disability in a manner consistent with the purpose of the CRPD must also be discharged by telecommunications authorities, which have regulatory power over the media, and, more importantly, for the purposes of this article, also deal with complaints over media broadcasts. This raises the question as to how the obligations imposed by Article 8 CRPD may be reconciled with concerns that encouraging the media to portray persons with disability in a manner consistent with the purpose of the CRPD may stifle public debate and make considerable inroads into the freedom of speech.

\section{MEDIA REGULATION WITH REGARDS TO THE RIGHT TO FREE SPEECH (UNDER ARTICLE 10 ECHR IN PARTICULAR) IN LIGHT OF ARTICLE 8 CRPD}

Balancing free speech with other legitimate concerns, as those indicatively mentioned in Article 10 of the European Convention on Human Rights (ECHR) (for example, protection of health or morals) is never an easy exercise. The approach that this article takes on the matter is the long view on the social exclusion and marginalisation of disability. Seen from such a historical perspective, measures and policies designed to redress this social injustice, by promoting social inclusion and diversity in the media, may be justified, even if they appear to make greater inroads in freedom of speech than those usually tolerated.

A good way to frame this issue comes from the work of Sottiaux and Rummens, ${ }^{23}$ who analyse the differing standards of protection accorded to the freedom of expression and freedom of association (with regard to political parties) by the case law of the European Court of Human Rights (ECtHR). The authors propose a model of concentric democracy which provides a more focused account of democracy, suitable to afford greater protection to both the freedom of expression and association. This view of concentric democracy combines elements from both a procedural as well as a substantive account of democracy. This concentric democracy is based on the abstract normative ideals of liberty and equality, which are then realised in specific, tangible ways through citizen participation. Citizen participation is best organised as a democratic process, whereby arguments, generated through civil society, NGOs and the media, influence deliberations in Parliament and the executive. In this account

22. Office of the United Nations High Commissioner for Human Rights (OHCHR), Rabat Plan of Action on the prohibition of advocacy of national, racial or religious hatred that constitutes incitement to discrimination, hostility or violence (2013) A/HRC/22/17/Add.4.

23. S Sottiaux and S Rummens, 'Concentric Democracy: Resolving the Incoherence in the European Court of Human Rights' Case Law on Freedom of Expression and Freedom of Association' (2012) International Journal of Constitutional Law 115. 
of concentric democracy as democratic process, participation in public debate is encouraged, and the concerns of all citizens are tracked. However, as these concerns and ideas progress through the public sphere towards parliamentary debate, they should be filtered according to their coherence with the substantive values of liberty and equality. By taking this account of concentric democracy as the basis of how disability should be portrayed in media broadcasts, it immediately becomes apparent that, in principle, all views about disability should be more or less freely voiced in informal public debate, whereas institutional public debate, in Parliament and the executive, should filter and limit that input to views that cohere with liberty and equality. Nonetheless, there may be good reasons why some views on disability should have limited input even in informal public debate. As mentioned, Article 8 CRPD places an obligation on States to encourage the media to portray persons with disabilities in a manner consistent with the purposes of the CRPD. It is doubtful if this obligation can be meaningfully fulfilled without raising the standards of broadcasts relating to disability, so that disablist language or comments are no longer acceptable. The balance between disability rights and free speech in media broadcasting has slightly shifted towards the protection of persons with disabilities.

So far, the first part of this analysis has summarily developed a normative account of Article 8 CRPD, based on its drafting history, as well as the wider context of disability rights, and examined the relationship between free speech in the media and disability. The next part of this article will analyse current law and practice on the representation of disability in the media. A brief analysis of how EU law on media regulation engages with disability will pave the way to the comparative analysis of disability-related complaints about audiovisual broadcasts in the UK and France.

\section{THE AUDIOVISUAL MEDIA SERVICES DIRECTIVE AND DISABILITY RIGHTS}

Media regulation did not become part of EU law until the Maastricht Treaty. Article 128 of the Maastricht Treaty (now Article 167 TFEU) imposed an obligation on the Community to "contribute to the flowering of the cultures of the Member States, while respecting their national and regional diversity'. The Community was permitted to supplement the action of Member States, in artistic and literary creation, including in the audiovisual sector. This article provided the normative foundation of the Television Without Frontiers Directive (TVWF), which the European Union adopted in $1998 .^{24}$ The TVWF was intended to open media markets in the European Union and determined the conditions for the free provision of TV services. Amongst other things, the TVWF also regulated the protection of minors and public order. The TVWF was updated by the AMSD with the aim to cover all broadcasting services and strengthen the single market for all media services. ${ }^{25}$

Even though neither the TVWF nor the AMSD specifically address the issue of cultural diversity, in contrast to the earlier TVWF Directive, the AMSD makes several

24. Council Directive (EEC) 89/552 on the coordination of certain provisions laid down by law, regulation or administrative action in Member States concerning the pursuit of television broadcasting activities [1989] OJ L298/23.

25. Directive (EC) $2007 / 65$ on the coordination of certain provisions laid down by law, regulation or administrative action in Member States concerning the pursuit of television broadcasting activities [2007] OJ L332/27. 
references to disability. This is not surprising, given that the EU is not only a signatory to the CRPD, but also actively contributed through its delegates to the drafting of the CRPD. Recital 46 and Article 7 of the Directive relate to the accessibility of audiovisual media services. Recital 104 states that the objectives of the Directive are 'the creation of an area without internal frontiers for audiovisual media services whilst ensuring at the same time a high level of protection of objectives of general interest, in particular the protection of minors and human dignity as well as promoting the rights of persons with disabilities'. Finally, Article 9(1)(c)(ii) imposes an obligation on Member States to ensure that audiovisual commercial communications shall not include or promote any discrimination based on sex, racial or ethnic origin, nationality, religion or belief, disability, age or sexual orientation. It is interesting to note that the specific reference of disability discrimination in commercial advertising echoes the discussions about Article 8 CRPD during the drafting process, where advertising was cited as a concern. For example, during the fourth session of the Ad Hoc Committee, in the afternoon session of 31 August 2004, the delegates of Israel proposed to add at the end of (the then) Article 5(1)(b) ('Combat stereotypes and prejudices about persons with disabilities'), the phrase 'including the perpetuation of stigmatization of PWD in advertising'. ${ }^{26}$ The delegates of Mexico commented that this is 'perhaps already addressed in 5(2)(c) which concerns the media.' 27

Even though a detailed analysis of the disability-related provisions of the AMSD is beyond the scope of this article, it is obvious that the Directive contains weak and incomplete regulation for promoting the rights of persons with disability: only accessibility and non-discrimination in commercial advertising are singled out. Even if this minimal approach can be justified by reference to the principle of subsidiarity of EU law, the fact remains that Article 9(1)(c)(ii) of the Directive falls greatly below the benchmark of Article 8 CRPD, which requires both positive measures towards awareness raising as well as the combatting of stereotypes against disability, only a small part of which is to ensure there is no discrimination in audiovisual commercial communications. Given the minimal regulation of disability awareness-raising in the AMSD, the implementation of Article 8 CRPD primarily falls to national authorities of States Parties to the CRPD. In order to better understand how Article 8 CRPD may impact on the disability-related practice of telecommunications authorities on a national level, the next section engages in a comparative analysis of several decisions on disability-related complaints in the UK and France.

\section{THE PROTECTION OF DIVERSITY AND DISABILITY IN MEDIA BROADCASTS IN FRANCE}

The Conseil Supérieur de l'Audiovisuel (CSA) is the broadcasting regulator in France. Set up by law No. 89-25 of 17 January 1989, its official mission is to guarantee the freedom of audiovisual communication in the country. The regulatory powers of the CSA are wide, and far-reaching. They are contained in law No. 86-1067 of 30 September 1986, as amended on various occasions, and include, inter alia: granting licences for broadcasters, supervising how electoral campaigns are broadcasted,

26. Ad Hoc Committee on a Comprehensive and Integral International Convention on Protection and Promotion of the Rights and Dignity of Persons with Disabilities, Fourth Session, Daily Summary of Discussions (2004).

27. Ibid. 
safeguarding pluralism of public opinion, the protection of minors, respect for human dignity, consumer protection, as well as the promotion of French language and culture. More recently, the CSA has been tasked with improving the accessibility of television programmes for persons with visual or auditory impairments, as well as ensuring that social diversity is represented in the media. Article 3-1 of law No. 86-1067 of 30 September 1986 states that the CSA contributes to actions which promote social cohesion and the fight against discrimination in the area of audiovisual communications. The CSA is charged with overseeing that broadcasts reflect the diversity of French society and making specific proposals to the French Parliament to increase diversity in broadcasting through its annual Reports. It is this particular function of the CSA which will be the focus of this section. It is argued that the CSA has undertaken important initiatives in relation to diversity. Despite these initiatives however, the representation of disability in French television is lacking, and the reasoning of the CSA in relation to a recent, high-profile case of disability-related complaints is flawed.

In order to promote its statutory duty to advance social cohesion, the CSA established in 2007 a working group on diversity, as well as a diversity observatory, which provides support to the CSA in the formulation of diversity policies regarding the media. Since 2009 , media diversity is annually measured through a diversity barometer, which aims to gauge the progress of media broadcasters in this area. The findings of the diversity barometer provide a detailed account of the representation of diversity in French media, and are analysed in the Report which the CSA annually submits to the French Parliament. According to the results of the 2015 diversity barometer ${ }^{28}$ disability continues to be disappointingly underrepresented in French television: the representation of disability in the media, as perceived by the audience is at $0.4 \%$. Without audience weighting, this percentage increases to $0.7 \% .^{29}$ These figures are but a minor improvement on the $0.2 \%$ disability-related figure of the initial diversity barometer of $2009 .{ }^{30} \mathrm{By}$ contrast, it is estimated that roughly $18.4 \%$ of the French population has some disability. The 2015 Report of the CSA also paints a grim picture with regards to the representation of disability in French media. The Report highlights that in July 2015, the CSA gave formal notice to a television broadcaster with regards to a negative comment on disability. ${ }^{31}$ During a talk show, a video was shown about a foreign music group appearing on the Eurovision song contest. The members of the group had Down syndrome and autism. This prompted one of the guests appearing on the show to comment 'we will fuck the trisomy people'. ${ }^{32}$ This comment, which caused some hilarity amongst the audience, was not challenged by the host of the show. The CSA rightly regarded that this comment stigmatises a group of people on the basis of their disability, and encourages discrimination. ${ }^{33}$ For these reasons, the CSA served a formal notice to the broadcasting company requesting that it will respect in the future, the values of integration and solidarity and combat discrimination, in accordance with the specific terms of its broadcasting licence. However, even though the CSA appears to be vigilant against any blatantly

28. CSA, Baromètre de la diversité (2015) <www.csa.fr/content/download/208917/557138/ file/barometre_csa_diversite_medias_2015.pdf> accessed 23 February 2017.

29. Ibid.

30. CSA, Baromètre de la diversité à la télévision (2009) <www.csa.fr/content/download/ 16666/310416/file/barometre_diversite_vague_1_20_oct_09.pdf > accessed 23 February 2017.

31. CSA, Rapport Annuel (2015) $21<$ www.csa.fr/content/download/216245/580039/file/ Rapport_annuel_2015.pdf> accessed 23 February 2017.

32. Ibid ('On va les niquer les trisomiques').

33. CSA, Décision No 2015-274 du 1er juillet 2015 portant mise en demeure de la société D8, JORF No 0215 du 17 septembre 2015 texte No 72. 
negative representation of disability in French media, the CSA's practice with regards to another case of disability-related complaints is more worrisome.

In 2014, several disability organisations produced together a short video entitled 'Dear future mom', which was uploaded on YouTube. ${ }^{34}$ One of these organisations was the Jérôme Lejeune Foundation, which opposes abortion. ${ }^{35}$ The video shows several people with Down syndrome responding to an email question of a future mother, who has discovered that her unborn baby has Down syndrome and asks 'I'm scared: what kind of life will my child have?'. The participants in the video demonstrate that a person with Down syndrome can lead a fulfilled life. During World Down Syndrome Day, on 21 March 2014, several French television channels broadcasted short clips from this video, translated as 'Chère future maman', during commercial breaks. Complaints about this broadcast were made to the CSA, which highlighted the connection between this video and the Jérôme Lejeune Foundation, as an organisation which opposes abortion. In its decision, the CSA held that, because the video was addressed to a future mother, its aim could appear ambiguous and upsetting. ${ }^{36}$ Similarly, the CSA held that the video was not of general interest, and therefore not suitable to be shown during commercial breaks. The CSA issued a subsequent press release to clarify that the video presented a positive view of life with Down syndrome and encouraged the social inclusion of persons with Down syndrome. However, the CSA also considered that the video could trouble viewers, especially women, who had opted for abortion on the grounds of disability. ${ }^{37}$ For these reasons, the CSA held that it was inappropriate to broadcast this video during commercial breaks, and that its message should have been presented in more suitable contexts, such as (disability-related) broadcasts.

The approach of the CSA to the broadcasting of the 'Chère future maman' video is based on the avoidance of controversy and distress which may be caused to viewers, especially women who had undergone abortion on disability grounds, and who might be suddenly confronted with this broadcast. Given that some of the disability organisations behind the video were against abortion, the CSA considered that the video's message could appear tainted with anti-abortion overtones. Be that as it may, this article argues that the approach of the CSA does not balance adequately the two goods at stake in this case: on the one hand, the discomfort of viewers who have chosen to abort foetuses with Down syndrome, and on the other hand, the effective dissemination of views that life with Down syndrome is worth living. Given that the CSA is charged with promoting social inclusion under French law, and the underrepresentation of disability in French media, the CSA should not have criticised the broadcasting of the video during commercial breaks, thereby reducing the visibility and impact of its message. Following the decision of the CSA, seven persons with Down syndrome, as well as the Jérôme Lejeune Foundation and the Organisation 'Les amis d'Eléonore'

34. CoorDown, 'Dear Future Mom' (13 March 2014) <www.youtube.com/watch?v=Juq4OnBtNU> accessed 23 February 2017.

35. CSA, 'Message de sensibilisation sur la trisomie 21: intervention auprès de M6 et de Canal+' (25 July 2014) <www.csa.fr/Espace-juridique/Decisions-du-CSA/Message-de-sensibilisationsur-la-trisomie-21-intervention-aupres-de-M6-et-de-Canal> accessed 23 February 2017.

36. Ibid.

37. CSA, 'Mise au point sur la décision du CSA en date du 25 juin 2014 relative à un message de sensibilisation sur la trisomie 21' (31 July 2014) <www.csa.fr/Espace-Presse/Communiques-depresse/Mise-au-point-sur-la-decision-du-CSA-en-date-du-25-juin-2014-relative-a-un-message-desensibilisation-sur-la-trisomie-21> accessed 23 February 2017. 
appealed to the Conseil d'Etat seeking to quash this decision. ${ }^{38}$ During the hearing of the case in September 2016, the public rapporteur of the Conseil d'Etat advanced the opinion that the case should be dismissed on the basis that the video was addressed to future mothers, aiming to influence them not to have an abortion, and as such could not be broadcast during commercial breaks. The subsequent judgment of the Conseil d'Etat confirmed that the CSA acted within its powers to regulate the broadcasting of the video in the way that it did, and on the basis of the reasoning advanced in its decision. ${ }^{39}$

Notwithstanding the intricacies of French law about commercial broadcasts and the general interest, the position of this paper is that the video's message is unrelated to abortion as such. The video does not criticise abortion on the grounds of disability, but rather focuses on informing future mothers about the positive value of life of persons with Down syndrome. Similarly it is this message, rather than the disability organisations which support it, which is the essence. In legal terms, as Article 3-1 of law No. 86-1067 of 30 September 1986 clearly states, broadcasting should not simply reflect the diversity of French society, but also contribute to actions promoting social cohesion. The broadcasting of such a video, which promotes positive views on the value of life of persons with Down syndrome, is such an action, which contributes to social cohesion by strengthening the social acceptance of disability. The recommendation of the CSA that this video should form part of transmissions relating to disability, rather than a standalone broadcast, reduces the impact of its message, and its effectiveness in combatting stereotypes about persons with Down syndrome. It follows that restrictions to its broadcast are incompatible with both the mission of the CSA, as set out in French law, as well as Article 8 CRPD.

\section{THE REGULATION OF DISABILITY-RELATED COMPLAINTS BY OFCOM UNDER UK LAW}

Compared to the wide regulatory powers of the French CSA, which cover a broad range of cultural aspects of broadcasting, from the promotion of social cohesion to the protection of the French language, the comparable UK regulator, Ofcom, which was set up by the Communications Act 2003, gives the impression of a communications regulator which is primarily concerned with the financial aspects of the industry. Section 3 of the Act requires Ofcom to advance the interests of citizens and of consumers, by promoting competition where appropriate.

In order to understand this apparent tension between the interests of both citizens and consumers, a short analysis of the Communications Act 2003 is required. Even though an in depth review of the Communications Act 2003 and Ofcom is beyond the scope of this article, ${ }^{40}$ it is important to understand the underlying tensions and the different policy considerations which exist in the Act and are reflected in the role of Ofcom. The Communications Act 2003 was adopted so as to combine the

38. C Heymelot, 'Au Conseil d'Etat, de jeunes trisomiques défendent leur droit à la parole' Le Monde (Paris, 8 September 2016) <www.lemonde.fr/societe/article/2016/09/08/au-conseil-detat-de-jeunes-trisomiques-defendent-leur-droit-a-la-parole_4994535_3224.html > accessed 23 February 2017.

39. Conseil d'Etat, Mme Z...et autres, Nos 384691, 384692, 394107, décision du 10 novembre 2016.

40. See, for example, P Smith, 'The Politics of UK Television Policy: The Making of Ofcom' (2006) Media Culture and Society 929. 
regulation of different communication industries, such as television and telecommunications. In so doing, the Communications Act 2003 redefined the principal role for governance and regulation as facilitating the conditions in which markets could operate dynamically, efficiently and effectively, namely through competition. However, this purely commercial approach to regulation was tempered by the adoption of public policy objectives, designed to protect the general public. Ofcom was therefore endowed with regulatory powers on the basis of competition rules as well as treatment of the media as a cultural force. ${ }^{41}$

Given the differences in regulatory focus between the broad-ranging powers of the CSA and the more commercially driven Ofcom, it is hardly surprising that the Communications Act 2003 does not impose any duty on Ofcom to promote social cohesion. On the contrary, even the concept of diversity is understood and protected differently by Ofcom. Section 27 of the Communications Act 2003, which relates to training and equality of opportunity, imposes a duty on Ofcom to take all such steps as they consider appropriate for promoting equality of opportunity in relation to employment, training and retraining, including the equalisation of opportunities for disabled persons. In other words, diversity in broadcasting is not about accurately reflecting social diversity in broadcasts, as in France, but rather to promote equality of opportunity for different social groups. The recent joint publication of the Equality and Human Rights Commission (EHRC) and Ofcom Thinking Outside the Box: Supporting the Television Broadcasting Industry provides guidance for the television broadcasting sector on lawful actions which can be taken in accordance with UK equality law in order to increase diversity in broadcasting. ${ }^{42}$ This article criticises this publication for omitting any reference to Article 8 CRPD with regards to awareness-raising about disability. Given that the Communications Act 2003 predates the CRPD and its ratification by the UK, this publication would have presented an excellent opportunity for the EHRC to place UK equality law with regards to disability and broadcasting in the wider context of Article 8 CRPD.

In relation to the cultural aspects of broadcasting, Section 3 of the Communications Act specifies the general duties of Ofcom, which include the application, in the case of all television and radio services, of standards that provide adequate protection to members of the public from the inclusion of offensive and harmful material in such services. Based on this regulatory power, Ofcom has adopted its Broadcasting Code. ${ }^{43}$ Section 2 of the Broadcasting Code, entitled 'Harm and offence' sets down in rule 2.1, that 'generally accepted standards must be applied to the contents of television and radio services so as to provide adequate protection for members of the public from the inclusion in such services of harmful and/or offensive material. ${ }^{44}$

Rule 2.3 of the Broadcasting Code mitigates this obligation by providing a defence of justification of offensive content through context:

In applying generally accepted standards broadcasters must ensure that material which may cause offence is justified by the context (...) Such material may include, but is not limited to,

41. Ibid.

42. Equality and Human Rights Commission and Ofcom, 'Thinking Outside the Box: Supporting the Television Broadcasting Industry' <www.ofcom.org.uk/_data/assets/pdf_file/ 0030/47496/increasing-diversity.pdf> accessed 16 March 2017.

43. Ofcom, 'The Ofcom Broadcasting Code (incorporating the Cross-promotion Code)' <www.ofcom.org.uk/_data/assets/pdf_file/0024/49308/Ofcom-broadcast-code-May-2016.pdf> accessed 16 March 2017.

44. Ibid 15 . 
offensive language, violence, sex, sexual violence, humiliation, distress, violation of human dignity, discriminatory treatment or language (for example on the grounds of age, disability, gender, race, religion, beliefs and sexual orientation). Appropriate information should also be broadcast where it would assist in avoiding or minimising offence. ${ }^{45}$

In this sense, when Ofcom receives a complaint relating to offensive language, it applies the appropriate rules within the Code taking into account the time of broadcast (pre or post-watershed) and considers the context in which the language is used and whether this provides adequate justification for its use. To inform Ofcom of generally accepted standards, Ofcom consults consumer research for an understanding of the general public's views on offensive language.

As to what may be justified by context, Ofcom has regard to an indicative list of factors, such as the editorial content of the programme, the service on which the material is broadcast, the time of broadcast, what other programmes are scheduled before and after the programme concerned, the degree of harm or offence likely to be caused by the inclusion of any particular sort of material in the programme, the likely size and composition of the potential audience and likely expectation of the audience, the extent to which the nature of the content can be brought to the attention of the potential audience for example by giving information, and the effect of the material on viewers or listeners who may come across it unawares. ${ }^{46}$ This extensive and indicative list of factors which make up the context of a programme, may all contribute to Ofcom ruling that there is no violation of rule 2.3 about offensive language. Based on the above considerations, Ofcom is ill-equipped to provide adequate protection against disablist language or attitudes in television programmes for a number of reasons.

First, as already mentioned, Ofcom has been primarily designed to regulate and oversee the UK telecommunications industries on the basis of competition rules, and, to a limited extent, with regards to the cultural aspects of broadcasting. This means that emphasis is placed on market values of laissez-faire capitalism. This is reflected in the wide discretion that Ofcom enjoys in justifying offensive content through context. Secondly, the concepts of offense and harm, which have been adopted by the Communications Act 2003 as well as the Broadcasting Code, are not precise enough to capture the harm of disablist language and attitudes in television programmes. Ofcom undertakes consultations with the general public, as well as specific focus groups to develop an up-to-date understanding of public attitudes towards offensive language.

In September 2016, Ofcom conducted a consultation with the UK public to update their existing knowledge around public attitudes in this area. ${ }^{47}$ The previous consultation on this issue had taken place in $2010 .^{48}$ Some of the key findings of the 2010 consultation include the following:

In terms of discriminatory language, 'nigger' and 'Paki' were seen as the most offensive words. Some participants thought it was acceptable to use them in some specific contexts (e.g. for educational use), whereas some thought they should not be used on television or

45. Ibid.

46. Ibid 16 .

47. Ofcom, 'Attitudes to Potentially Offensive Language and Gestures on TV and Radio' <www.ofcom.org.uk/_data/assets/pdf_file/0022/91624/OfcomOffensiveLanguage.pdf> accessed 16 March 2017.

48. Ofcom, 'Audience Attitudes towards Offensive Language on Television and Radio' <www.ofcom.org.uk/_data/assets/pdf_file/0017/27260/offensive-lang.pdf > accessed 16 March 2017. 
radio in any context. The word 'spastic' was also generally considered unacceptable. Some discriminatory language polarised responses, particularly 'retarded', 'gyppo', 'pikey', 'gay' and 'cripple' as participants' familiarity with and interpretation of, these words varied greatly, both within the general UK sample, and between the general UK sample and the minority groups. Overall, most potentially offensive words were not seen to be unacceptable in principle, as context was a key factor in determining whether language was seen as generally acceptable or unacceptable. The exception to this was some potentially discriminatory language (particularly 'Paki', 'nigger' and 'spastic') which some participants considered unacceptable in any context. ${ }^{49}$

Some of the key findings of the 2016 consultation include the following:

Views on words relating to mental health and disability differed greatly. Words such as 'spastic', 'mong' or 'retard' were seen as insulting and derogatory, and therefore viewed as being as unacceptable as the strongest racist insults, with their use requiring significant contextual justification. On the other hand, words such as 'nutter', 'loony' or 'mental' were seen as more commonly-used mild insults, and were therefore much more acceptable, both before and after the watershed. ${ }^{50}$

As the findings of these consultations show, it is hardly to be expected that generally acceptable standards about offensive language may be found in either the general public or in specific focus groups. However, the absence of public consensus on offensive language does not mean that disablist language and attitudes may be justified through context. On the contrary, the interpretation of what constitutes a generally accepted standard with regards to the representation of disability in the media has now to take into account the international human rights standard of the CRPD with regards to disability. In other words, Ofcom should update its understanding of offensive language with regards to disability. Based on Article 8 CRPD, read in conjunction with Article 1 CRPD television programmes which contain disablist language or attitudes should be regarded as contravening the Broadcasting Code and can only exceptionally be justified by context (for example, in educational programmes about disability). This approach, based on the CRPD, the social model of disability, the concept of disablism and a nuanced account of public debate, is not only consistent with the right to freedom of speech under Article 10 of the ECHR, but is also very different from the way that Ofcom, in its supervisory role over the UK communications industries, has dealt with disability-related complaints. It is therefore time to turn to Ofcom and examine an important case on this issue.

One clear example of the failings of Ofcom with regards to disability-related complaints concerns Ricky Gervais's comment on his show Science about Susan Boyle. ${ }^{51}$ Gervais claimed that Susan Boyle looked like a mong and added that: 'even if they do ban me from the telly, I'll just go around and shout 'mong' through their window. I care about it that much. It's just words, and there is no better word to describe Susan Boyle'. Gervais then explained that his use of the term was distinct from its connotations as a pejorative term for a person with Down syndrome. He then went on to talk about how language and the meaning of words change, with Gervais contending that the derivation of words does not matter, since words change. Ofcom ruled that Gervais's comment was not in breach of the Broadcasting Code.

49. Ibid 12-13.

50. Ofcom, 'Attitudes to Potentially Offensive Language and Gestures on TV and Radio' (n 47) 41.

51. Ofcom, Broadcast Bulletin, Issue 198 (2012) 46 <www.ofcom.org.uk/__data/assets/ pdf_file/0023/51179/obb198.pdf> accessed 16 March 2017. 
As mentioned above, this article argues that generally accepted standards and offensive language in broadcasts about disability must be interpreted in the light of the social model of disability: disablist language and disablist representations of persons with disabilities in the media, such as television, are not permissible under Article 8 CRPD, read together with Article 1 CRPD. The trouble with Gervais's approach to language is that it adopts an ableist perspective, which fails to appreciate the viewpoint of persons with disabilities, as well as the history of stigma of such words in their social context. Calling a person with Down syndrome a 'mong' is disablist, because it perpetuates labelling and negative stereotypes towards persons with intellectual disability. The same however can be said if this abusive word is directed against a nondisabled person. Even if the meaning of words change, as Gervais contends, many people are still troubled and disadvantaged by the history and the associations of stigmatising vocabulary. What captures the essence of any disablist representation in the media is the underlying assumption that persons with disabilities are inferior to others, which is inferred by using the word 'mong' in a derogatory way. In this respect, the initial, historical derivation of the word 'mong' from the term 'mongoloid' has indeed been phased out in the modern usage of the term. Given its derogatory meaning however, allowing such a word to be broadcast in television goes against Article 8 read in conjunction with Article 1. Simply put, such words are not only offensive; they are disablist, because they perpetuate labelling, in spite of any assertions to the contrary. As such, disablist language should not be broadcast, as it can rarely be justified through the context of the broadcast. Offensiveness has to be understood not only in relation to the sensitivity of the public towards specific language, but also in relation to disablist attitudes, which engender damaging stereotypes about disability. For this reason, the justification for including such language in a television programme by reference to its context needs to be of a very high standard (for example, educational purposes) or relate to the function of the press as a public watchdog. ${ }^{52}$ This approach to disablist comments on television is coherent with the right to free speech under Article 10 ECHR, read in light of Article 8 CRPD, because it aims to encourage all organs of the media to portray persons with disability in a positive light.

Equally problematic is Ofcom's decision with regards to disability-related complaints made against Frankie Boyle's jokes in his comedy series Tramadol Nights. ${ }^{53}$ Ofcom reviewed the jokes to establish whether these were offensive. Having ascertained that the jokes were offensive, Ofcom considered that the broadcaster had not applied generally accepted standards to justify the inclusion of that material by the context of the programme. Ofcom considered that this case involved an erroneous decision on a matter of editorial judgement on the broadcaster's part. In the second episode of Tramadol Nights, Frankie Boyle made two jokes about Katie Price's 8 year-old son, Harvey, who has a medical condition and learning difficulties. Frankie Boyle said that Katie Price and her ex-husband were fighting over the custody of Harvey, but eventually one of them would have to lose and keep him. Boyle's second joke referred to Harvey's large size and claimed that Katie Price married a second time to a cage fighter to protect her from Harvey's sexual advances.

52. See Jersild v Denmark (1994) 19 EHRR 1. By contrast, in Hagan v Australia, which did not involve the press, the Committee on the Elimination of Racial Discrimination was able to take a more robust stance against racially offending terms. See Hagan v Australia, Comm. 26/2002, U.N. Doc. A/58/18 139 (2003).

53. Ofcom, Broadcast Bulletin, Issue 179 (2011) 47 <www.ofcom.org.uk/_data/assets/ pdf_file/0028/46729/obb179.pdf> accessed 16 March 2017. 


\section{As Ofcom's decision states:}

Solicitors acting on behalf of Katie and Harvey Price complained to Ofcom that the comments were discriminatory, offensive, demeaning and humiliating. The solicitors informed Ofcom that Harvey has a condition called septo-optic dysplasia, and is also on the autistic spectrum. The solicitors stated that "Harvey has very restricted sight, needs constant medication and has learning difficulties. Harvey, as a result of his condition and medication is large and strong for his age". Ofcom also received approximately 500 complaints about the comments, including, from the learning disability charity Mencap and from the Royal London Society for the Blind. In summary, the complainants stated that it was highly offensive, discriminatory and abusive to broadcast these comments about an eight year-old disabled child. The complainants were also offended that the comments named a child as engaging in rape and incest. ${ }^{54}$

Ofcom considered that the jokes did not hinge on satire about Katie Price and her marital affairs. On the contrary, the jokes had a straightforward focus on Harvey Price and his disability. In the first joke, Frankie Boyle's inference was that Harvey's disability would be a burden to the parent who would keep custody over him. The second joke focused on Harvey's size, which is known to be linked to his mental and physical disability. Ofcom concluded that the inference here was that Harvey's disability also involved a threat to his mother's safety. Taking into account all of the above factors, Ofcom was of the view that the material in question appeared to directly target and mock the mental and physical disabilities of a known 8 year-old child who had not himself chosen to be in the public eye. As such, Ofcom found that the comments had considerable potential to be highly offensive to the audience. Furthermore, Ofcom considered that, even taking into account contextual factors such as the nature of the series as a whole, its scheduling, publicity and the clear pre-transmission warning, these comments went beyond what would have been expected by the majority of viewers of a late night comedy show broadcast on Channel 4. In finding a breach of the Broadcaster's Code, Ofcom did consider that this case involved an erroneous decision on a matter of editorial judgement on the broadcaster's part, and was not indicative of a general, systemic failure of the broadcaster to follow generally accepted standards.

The reasoning employed by Ofcom in reaching this decision relies heavily on considerations of offensiveness (in order to find a violation) and context (in order to justify the broadcast). As such, the reasoning in the decision is based on subjective standards of offensiveness, which are being gauged by consumer research. Such subjective standards, even if they are deemed to apply to the general population, as general standards of offensiveness have two important drawbacks. First, they can never capture every nuance of disablist language in television and secondly, these standards of offensiveness may fall down as well as go up. To give an example, can the term 'benefit scrounger' be regarded as highly offensive with regards to people with disabilities? In the 2010 consultation of Ofcom, this term has not featured among the words discussed with the public. Similarly, the focus on generally accepted standards obfuscates the issue that some forms of speech cannot be protected as free speech. This is when some forms of speech violate legal standards, such as the standard set by Article 8 CRPD: all organs of the media should be encouraged to portray persons with disabilities in a manner consistent with the purpose of the CRPD.

Rewriting Ofcom's reasoning from the viewpoint of the CRPD results in a far more objective analysis, based on disablism as the benchmark against which

54. Ibid 5 . 
generally accepted standards may be measured. In this sense, Ofcom should have remarked that the two jokes Frankie Boyle made about Harvey referred directly to his disability and inferred that having the custody of a child with disability is a burden, as well as a potential threat to the parent's sexual safety. By so doing, Boyle reproduces negative stereotypes of persons with disability as burdens on society. Similarly, Boyle's second joke reinforces social prejudices about persons with disability as having uncontrollable sexual desires. Boyle's jokes trivialise disability and reproduce negative stereotypes about persons with disability, which conform to disablist perceptions about disability. Ofcom should have highlighted the inherent disablism of Boyle's jokes and should have taken this disablism as the basis of the offensiveness of Boyle's jokes. Given that the content of the broadcast was disablist, Ofcom should also have argued that the potential margin for justifying the inclusion of such disablist material was extremely narrow and could certainly not be covered by the context of the show, such as the nature of the series as a whole, its scheduling, publicity and its clear pre-transmission warning. ${ }^{55}$ At the same time, Ofcom should have noted that, as the regulatory body of the communications industries in the UK, it should take into consideration Article 8 CRPD when developing standards that provide adequate protection to members of the public from the inclusion of offensive and harmful material, according to section 3 of the Communications Act. In light of the CRPD, these standards of the Broadcasting Code must be such as to encourage all organs of the media to portray persons with disabilities in a manner consistent with the CRPD. For this reason, Ofcom should also have made a recommendation to the broadcaster to set down clear and unambiguous editorial guidelines about disablist broadcast material.

\section{CONCLUSION}

This article has attempted to provide a normative account of Article 8 CRPD, by focusing in particular on the obligation imposed on States Parties to encourage all organs of the media to portray persons with disabilities in a manner consistent with the purpose of the CRPD. Awareness-raising is a vital issue for protecting disability rights and promoting social inclusion and equality for persons with disability. It is clear from the comparative analysis of both EU law, as well as national legislation, in both France and the UK, that the current regulatory framework on broadcasting services is inadequate to fulfil this obligation in a meaningful way. At the same time, Article 8 CRPD raises difficult questions with regards to the balance between freedom of speech and the promotion of social inclusion for persons with disabilities. This is particularly evident in the current practice of broadcasting regulators, which fail to take into account a CRPD perspective on disability-related complaints. The comparative analysis of how broadcasting regulators in France and the UK have considered disability-related complaints shows that disability rights considerations are yet to inform how such complaints are being handled. This lack of effective implementation is an infringement not only of Article 8 CRPD, but also a violation of the

55. This line of argument must not be taken to mean that context should not be taken into account at all. Generally speaking, context may be crucial for determining the appropriateness of broadcasts. However, for disability-related issues, it seems clear that, under Article 8 CRPD, the media should not be able to escape appropriate sanctions for broadcasting disablist material on the basis of context. 
general obligations under Article 4 CRPD to adopt all appropriate legislative, administrative and other measures for the implementation of CRPD rights, as well as refrain from engaging in any act or practice that is inconsistent with the CRPD and to ensure that public authorities and institutions act in conformity with the CRPD. Both the regulatory framework for broadcasting, as well as the practice of the relevant regulatory bodies are in need of careful revision, in order to conform to the obligations imposed by Article 8 CRPD. 